\title{
Sherlock detected
}

\author{
By Rosanna Miller
}

Head, Map Collection and Exhibits Coordinator

Arizona State University

\section{A step-by-step guide to an exhibit that leads students through the process of gathering information.}

$\mathrm{n}$ the spring of 1989, Maxine Reneker, ardent Sherlockian and - at that time-associate dean for public services, Arizona State University Libraries, suggested mounting a Sherlock Holmes exhibit that would promote library instruction. The plan was to identify queries, not exclusively literary, related to the Holmesian canon, retrieve relevant information through as many in-house databases as possible, and design displays for the ASU Libraries to introduce students painlessly to various avenues of research via questions and answers that could easily be understood.

As exhibits coordinator for Noble Science and Engineering Library, I was charged with developing the Sherlockian display highlighting the sciences. Despite a lifelong addiction to reading, I knew little of Sherlock, and the prospect of quickly retrieving a few scientific nuggets from an unexplored literary landslide was daunting.

This article describes the Noble Library exhibit as developed from the initial idea. One vertical and four horizontal cases were used.

\section{Case 1}

The introductory display featured two large signs: "Detecting Sherlock Holmes in the ASU Libraries," identifying the theme of the exhibit, and "Vital Clues on Display," directing the viewer to additional displays. This vertical case was backed by "The Booklover's Map of the British Isles," with a Sherlock Holmes caricature on an inset map of London. A one-page introductory placard, with Sherlock logo, read as follows: Sherlock Holmes Detected in the Arizona State University $\mathrm{Li}$ braries. "Sherlock Holmes is one of the most enduring and popular fictional characters of all time. More literature has been written about the Sherlockian stories than about any other literary work, with the exception of the Bible and Shakespeare's plays.

"This exhibit illustrates the use of many of the information sources and the finding tools in the ASU Libraries available to assist Sherlockian researchers who wish to learn more about the famous detective and his creator, Sir Arthur Conan Doyle.

"Material has been gathered from many specialized collections as well as from the general stacks, with some additions of memorabilia from personal collections of local members of 'Moulton's Prospectors,' the local Scion Society of the Baker Street Irregulars.

"Hayden Library and the Damiel E. Noble Science and Engineering Library both are currently featuring Sherlockian displays. The indexes and finding aids cited in the exhibit may be consulted at the Information and Reference Desks at Noble and Hayden as well as at other public service points within each library.

"If you are already a fan of Sherlock Holmes, we hope you will enjoy the exhibit. If you are as yet unacquainted with the stories about this legendary 
figure, read on. Perhaps you'll find something to pique your interest in the adventures of the master detective."

A smaller "Clue Card" set forth the first question, the procedure to follow, and the answer.

Query 1: 'Was Sherlock Holmes' address, No. 221B Baker Street, a real location?"

Procedure: "Go to online catalog terminal; select Encyclopedia database; do word search on 'Baker Street' and 'Sherlock Holmes.' Switch to Maps database; do word search on 'England, Literature' and 'London 1870.' Switch to General Catalog database; do word search on 'Baker Street' and 'Sherlock Holmes'; select The Encyclopaedia Sherlockiana; locate in Hayden stacks; look up 'Baker Street.' "'

Answer: "The Encyclopaedia Sherlockiana states, There is no No. 43 , nor is there a No. 221. Sherlock Holmes' legendary address, 221 Baker Street, is clearly a disguise for the actual number."

Other components of the display were a characteristic pipe, a deerstalker cap, a Sherlockian toby mug, and a color portrait of Sherlock Holmes, a.k.a. Jeremy Brett of the BBC's Sherlock Holmes television series. Additional printed material included a copy of "The Ballade of Baker Street," highlighted printouts from the encyclopedia, maps, and general catalog databases, and copies of cited pages from The Encyclopaedia Sherlockiana.

\section{Case 2}

The Adventure of the Speckled Band: "At first I thought that she had not recognized me, but as I bent over her she suddenly shrieked out in a voice which I shall never forget, 'Oh, my God Helen! It was the band! The speckled band!"”

Query 2: "What was the speckled band?"

Procedure: "Go to online catalog terminal; select General Catalog database; do word search on 'Sherlock Holmes'; select The Encyclopaedia Sherlockiana; locate in Hayden stacks; look up 'Speckled Band' to find 'See "Swamp Adder." 'Retum to online catalog terminal; select Encyclopedia database; do word search on 'Adder.' Switch to General Catalog database; do word search on 'Snakes, India.' Switch to General Sciences database; do word search on 'Snakebite." "

Answer: "Always follow through on your cross references. 'See Swamp Adder' leads directly to 'Swamp Adder...Holmes called it "the deadliest snake in India."...There is no snake known as a "Swamp Adder" and the serpent as described fits no known species, Indian or otherwise. "

This case featured portraits of Dr. Roylott and Helen Stoner from the BBC series, a "speckled band," formerly a dress belt, highlighted printouts from the General Catalog, Encyclopedia, and General Sciences databases, and four books identi- fied via the General Catalog. In addition to The Encyclopaedia Sherlockiana, the books displayed were: Snakes; biology, behavior, and relationship to man, with color photo of snake charmers; Handbook of Snake-bite by Paresh Banerji, with color photo of deadly speckled snake, and The Snakes of India and Pakistan by Lieutenant Colonel K.G. Gharpurey, with a serendipitous tribute to the perspicacity of the great detective: "As this book is most likely to be in the hands of laymen and the public, I shall not mention the ingenious ways of killing that never lead to detection even by expert jurists; lest evil-minded persons should learn the art by reading this book."

\section{Case 3}

The Adventure of the Engineer's Thumb: " 'We are now,' said he, 'actually within the hydraulic press, and it would be a particularly unpleasant thing for us if anyone were to turn it on. The ceiling of this small chamber is really the end of the descending piston, and it comes down with the force of many tons upon this metal floor. "

Query 3: "Where can I find some past and present uses of the hydraulic press?"

Procedure: "Go to online catalog terminal; select Encyclopedia database; do word search on 'Hydraulic Press.' Switch to General Catalog database; do word search on 'Hydraulic Press,' 'Hydraulic Presses,' 'Hydraulic Power,' 'Hydraulics History.' Switch to General Sciences database; do word search on 'Hydraulic Presses.' Switch to Applied Science and Technology database; do word search on 'Hydraulic Presses.'

Answer: "The multiple references suggest a variety of uses for the hydraulic press, including the forging of metals."

The attention-getter for this display was a lifesize hand with the thumb cut off and blood "pouring" from the wound, mounted on a black background. This effect was staged with a color photo snipped from a magazine ad (not library property), a cheese slicer (i.e., a "weapon like a butcher's cleaver," and a liberal application of red ink. The "cleaver" was held upright by a bar of soap concealed by the mount. On the same background were mounted an illustration of Joseph Bramah's hydraulic press from a publication of 1816 , reprinted in How it Works: the Illustrated Encyclopedia of Science and Technology, a simple definition of a hydraulic press, a diagram demonstrating the principle of its operation, and a synopsis of the story. In the established pattern, the display included two other books, The Hydraulic Age and History of Hydraulics, identified through the General Catalog, and printouts from the Encyclopedia, General Catalog, General Sciences, and Applied Science and Technology databases. A 
smaller mutilated hand, once a replica on a plastic key chain, supplemented the Grand Guignol visuals.

\section{Case 4}

A Study in Scarlet: "The campaign brought honors and promotion to many, but for me it had nothing but misfortune and disaster...I was struck on the shoulder by a Jezail bullet, which shattered the bone and grazed the subclavian artery."

Query 4: "What are some possible consequences of an injury to the subclavian artery?"

Procedure: "Go to Science Reference Desk; make appointment to use Medline CD-ROM; keep appointment; study tutorial and do word search on 'subclavian artery injury.' Go to online catalog terminal; select General Sciences database; do word search on 'subclavian arteries.' Switch to General Catalog database; do word search on 'Sherlock Holmes, Medicine'; select 'Diagnosis and Detection'; locate in Hayden stacks; look up 'Watsonian Deficiencies.' "

Answer: "There are numerous after effects of subclavian artery injuries, as Medline CD-ROM citations indicate. Additionally, Diagnosis and Detection speculates: 'A fourth (though highly unlikely possibility) is that the good doctor suffered from a subclavian steal syndrome in which a vascular obstruction siphons blood from the vertebralbasilar arterial system, thus causing cerebral ischemia with the attendant symptoms of forgetfulness, mental confusion, fatigue, and fainting. ' "

This display was centered by a color portrait of one of the two Dr. Watsons of the BBC series and the first map from "The World Strictly According to Doyle," copyrighted by Julian Wolff in 1940. The Indian subcontinent, where Dr. Watson served as an army surgeon, was spotlighted by a magnifying lens or glass, an indispensable tool in Holmes's crime detection methods. The featured book was Diagnosis and Detection. As before, the relevant printouts and a synopsis of the story completed the display.

\section{Case 5}

A Study in Scarlet: "I followed...and succeeded in reaching Candahar in safety.... I served at the fatal battle of Maiwand.... Murray, my orderly,...threw me across a pack-horse, and succeeded in bringing me safely to the British lines. Worn with pain, and weak from the prolonged hardships which I had undergone, I was removed ...to the base hospital at Peshawur."

Query 5: "Was Candahar to Peshawur a long, hard way to go?"

Procedure: "Go to online catalog terminal; select Encyclopedia database; do word search on
'Kandahar' (Candahar). Switch to Maps database; do word search on 'Afghanistan' and select No. 12; do word search on 'Afghanistan Shaded Relief and select No. 4; locate maps in Map Collection; locate cities on maps and note intervening topography."

Answer: "Are you kidding? Over 400 miles of bad road, gravely wounded, and on a pack-horse, yet!"

"Afghanistan," 1982, in shaded relief, and "Part of Southern Afghanistan with Adjoining Portion of Baluchistan," 1878-1880, showing topography, were used as background for the final display. Large black arrows, cut from construction paper, pointed the locations of Qandahar (Candahar) and Peshawar (Peshawur) on the modern-day map and Kandahar (Candahar) on the old map dating from the British raj. A red circle, similarly fashioned, pinpointed the location of the "fatal battle of Maiwand." Printouts, a reduced portrait of Watson, and two copies of A Study in Scarlet completed the display.

\section{Conclusion}

The Sherlock Holmes exhibit was highly successful and cost almost nothing. With no established budget for exhibits, cost is always an important factor. An original poster with a Sherlock Holmes logo and the two larger signs were the creations of Wayne Hulgin, graphic artist for library instruction. Sherlockian memorabilia, photos, and miscellaneous artifacts were loaned by Maxine Reneker, Rosanna Miller, and Jim Stute, of the ASU Libraries. The exhibit was designed and executed by Rosanna Miller, adhering closely to Maxine Reneker's initial proposal.

There is a greatly overused saying, "If you've got a lemon, make lemonade." We like to think we added the magic ingredient, imagination, to our limited budget lemonade and made some rather tasty champagne punch!

\section{Conference on librarians in international development}

"Information management in the developing world" is the theme of the Third National Conference on Librarians in International Development to be held April $28-30$ at Oregon State University in Corvallis. The conference is cohosted by OSU and Washington State University. Keynote speaker will be Paul Findley, BIFADEC member and coauthor of Title XII. For more information, contact: Shirley Scott, Kerr Library, Oregon State University, Corvallis, OR 97331-4501; (503) 737-3260; e-mail SCOTTS@ORSTATE.BITNET. 


\section{FES INDEX plus TEXT on COMPACT DISC}

\section{Developed for Public and Academic Libraries}

Indexes, abstracts and full text ...

- for all manufacturing and service industries

- from more than 1,000 key business and trade publications

- covering North America, Europe, Latin America and the Pacific Rim

- available with SilverPlatter Information Retrieval Software

Plus, you own the annual archival disc, and there's no extra charge for LANs!

\section{For more information and a free brochure, call Predicasts today!}

